\title{
PENGARUH LIKUIDITAS DAN FREE CASH FLOW TERHADAP KEBIJAKAN DIVIDEN DENGAN GOOD CORPORATE GOVERNANCE SEBAGAI VARIABEL INTERVENING
}

\author{
Oleh : \\ Yuningsih Nita Christiani ${ }^{1}$, Ananius Donatus Rure ${ }^{2}$ \\ Universitas Kristen Artha Wacana
}

\begin{abstract}
Abstrak
Penelitian ini ingin mengetahui tentang Pengaruh Likuiditas dan Free Cash Flow terhadap Kebijakan Dividen dengan Good Corpotate Governance sebagai Variabel Intervening”.penulis mengembangkan penelitian tersebut dengan menambah 2 variabel baru untuk diteliti dan menambah jumlah sampel perusahaaan dikarenakan dari hasil analisis sebelumnya yang dilakukan oleh Sulistiyowati, Anggaraini, dan Utaminingtyas (2010) menunjukkan bahwa dengan analisis regresi berganda tidak ada satupun variabel independen dan variabel kontrol yang secara statistik berpengaruh terhadap kebijakan dividen. Begitu pula dengan pengujian path analysis yang menyatakan bahwa profitabilitas, leverage, dan growth tidak mempunyai pengaruh terhadap kebijakan dividen dengan good corporate governance sebagai variabel intervening.

Peneltian ini menggunakan analisis regresi berganda dengan sampel yang digunakan pada penelitian ini adalah perusahaan manufaktur yang bergerak dalam bidang perdaggangan dan perindustrian yang masuk dalam pemeringkatan Corporate Governance Perception Index (CGPI) yang dilakukan oleh The Indonesian Institute for Corporate Governance (IICG) tahun 2016,2017 dan 2018 serta menerbitkan laporan keuangan per 31 Desember. Penelitian ini menggunakan metode penggabungan (pooled data untuk tahun 2016,2017 dan 2018).

Hasil penelitian ini Nilai koefisien regresi Likuiditas (X1) 0,105 dan tingkat signifikan 0,805,dan koefisien regresi likuiditas -115 dan tingkat signifikan 0,790.Berdasarkan hasil yang ditinjau dari nilai signifiknasinya diatas dapat disimpulkan bahwa likuiditas dan free cash flow tidak memiliki pengaruh terhadap kebijakan dividen.Hal ini dikarenakan nilai signifikanya diatas 0,05 dan sesuai dengan standar yang ada bahwa dapat dikatakan signifikan apabila dibawah 0,05.Hal ini menunjukan bahwa hipotesis 1 (H1) dan hipotesis 2 (H2) ditolak, dimana tidak ada pengaruh likuiditas dan free cash flow terhadap kebijakan dividen.

Hasil Uji T tanpa ditambahkan variabel interveningnya adalah pada ikuiditas sebesar-0,583 dan free cash flow -0,722. Sedangkan hasil Uji T setelah ditambahkan dengan variabel interveningnya yaitu good corporate governance berubah untuk likuiditas menjadi 0,254 dan free cash flow -275. Hasil diatas menunjukan bahwa Hipotesis 3 (H3) dapat diterima yaitu terdapat pengaruh likuiditas dan free cash flow terhadap kebijakan dividen dengan good corporate governance sebagai variabel intervening.
\end{abstract}

Kata Kunci: Likuiditas,Free Cash Flow, Good Corporate Governance, Kebijakan Deviden 


\section{PENDAHULUAN}

Dengan kemajuan Ilmu pengetahuan dan teknologi serta perkembanganya yang sangat pesat membuat persaingan di dunia usaha sangat ketat. Suatu perusahaan harus mampu bersaing dengan perusahaan yang lain dengan cara berinovasi dan mengembangkan usahanya tersebut untuk dapat melangsungkan kehidupan usaha, Terdapat dua sumber penyediaan dana dalam perusahaan yaitu yang berasal dari dalam perusahaan dan berasal dari Luar perusahaan.Sumber penyediaan dana yang berasal dari dalam perusahaan berupa pemanfaatan laba yang ditahan yang merupakan laba yang tidak dibagikan sebagai dividen. Sedangkan sumber dana diluar perusahaan diperoleh dengan melakukan pinjaman kepada pihak lain atau dengan menjual saham kepada calon investor di pasar modal.

Tujuan para investor menginvestasikan dananya kepada suatu perusahaan adalah untuk memaksimalkan return tanpa mengabaikan risiko yang akan dihadapinya. Investor akan sangat senang apabila mendapatkan tingkat pengembalian investasinya semakin tinggi dari waktu ke waktu. Oleh karena itu, investor dan investor potensial memiliki kepentingan untuk mampu memprediksi berapa besar tingkat pengembalian investasi mereka. Investor akan membuat keputusan apakah harus menginvestasikan atau menahan dana yang dimilikinya berdasarkan laporan keuangan yang diterbitkan oleh suatu perusahaan.

Para calon investor melakukan penilaian terhadap prospek kinerja perusahaan, karena pada umumnya hampir semua investasi mengandung unsur ketidakpastian sebelum mengivestasikan danaya. Kebijakan dividen suatu perusahaan akan melibatkan dua pihak yang berkepentingan dan saling bertentangan, yaitu kepentingan pemegang saham yang mengharapkan dividen, dengan kepentingan perusahaan terhadap laba ditahan. Setiap perusahaan mempunyai kebijakan dividenya masingmasing dalam melakukan pembagian dividen yang dibayarkan perusahaan kepada investor selaku pemegang saham. Beberapa perusahaan yang dapat menghasilkan laba yang besar tetapi hanya memiliki kesempatan investasi yang terbatas pada umumnya mendistribusikan sebagian besar uangnya kepada pemegang saham sehingga dapat menarik minat para pemegang saham yang menyukai dividen yang tinggi.

Para investor biasanya lebih senang membayar dengan harga yang lebih tinggi bagi saham yang akan dapat memberikan dividen yang tinggi. Sehingga pembayaran 
dividen yang tinggi dapat menarik para investor untuk menanamkan modalnya kepada perusahaan. Dividen dianggap memberatkan bagi sebagian perusahaan karena perusahan harus selalu menyediakan sejumlah kas dalam jumlah yang relatif permanen untuk membayarkan dividen di masa yang akan datang. Perusahaan yang tidak memiliki dana namun harus tetap mengeluarkan dividen dapat mengakibatkan dana untuk kebutuhan investasinya berkurang sehingga memerlukan modal tambahan baru dengan menerbitkan saham baru atau melakukan pinjaman kepada pihak lain.Likuiditas perusahaan merupakan pertimbangan utama dalam banyak kebijakan dividen karena dividen bagi perusahaan merupakan kas keluar, maka semakin besar likuiditas perusahaan secara keseluruhan akan semakin besar kemampuan perusahaan untuk membayar dividen (Sartono, 2001: 293). Menurut free cash flow hypothesis ketika perusahaan memiliki kelebihan kas, maka yang dibutuhkan adalah mendanai proyek yang memiliki Net Present Value (NPV) positif. Tetapi lebih baik bagi manajer untuk mengembalikan kelebihan kas kepada pemegang saham dalam bentuk dividen guna memaksimumkan kekayaan pemegang saham. Hal tersebut menunjukkan bahwa dividen dapat mengurangi agency cost karena mengurangi free cash flow yang tersedia bagi manajer.

Dalam Era Masyarakat Ekonomi Asean,para investor dalam hal menanamkan modalnya pada suaru perusahaan tidak hanya melihat dari jumlah keuntungan perusahaan pertahunya,tetapi juga melihat dari kondisi internal perusahaan seperti transparansi, akuntabilitas, rensposibility, Independensi,serta kewajaran dan kesetaraan.Pada era ini juga,para investor sudah mulai menanamkan modalnya dengan melihat pada perusahaan yang masuk dalam pemeringkatan Good Corcporate Governance. Sejarah lahirnya GCG muncul atas reaksi para pemegang saham di Amerika Serikat pada tahun 1980-an yang terancam kepentingannya (Budiati, 2012). Maraknya skandal perusahaan yang menimpa perusahaan - perusahaan besar, baik yang ada di Indonesia maupun yang ada di Amerika Serikat, maka untuk menjamin dan mengamankan hak-hak para pemegang saham, muncul konsep pemberdayaan komisaris sebagai salah satu wacana penegakan GCG. Di Indonesia, konsep GCG mulai dikenal sejak krisis ekonomi tahun 1997 krisis yang berkepanjangan yang dinilai karena tidak dikelolanya perusahaan-perusahaan secara bertanggungjawab, 
serta mengabaikan regulasi dan sarat dengan praktek (korupsi, kolusi, nepotisme) KKN (Budiati, 2012).

Bermula dari usulan penyempurnaan peraturan pencatatan pada Bursa Efek Jakarta (sekarang Bursa Efek Indonesia) yang mengatur mengenai peraturan bagi emiten yang tercatat di BEJ yang mewajibkan untuk mengangkat komisaris independent dan membentuk komite audit pada tahun 1998, Corporate Governance (CG) mulai di kenalkan pada seluruh perusahaan publik di Indonesia. Untuk menghindari terjadinya penyalahgunaan wewenang antara pihak manajemen dengan kepentingan pemegang saham, Perusahaan menyepakati penerapan Good Corporate Governance (GCG) suatu sistem pengelolaan perusahaan yang baik untuk mencapai tujuan dan mengawasi kinerja perusahaan. GCG bertujuan untuk Melindungi hak dan kepentingan pemegang saham,melindungi hak dan kepentingan para anggota stakeholders non pemegang saham,meningkatkan nilai perusahaan dan para pemegang saham,meningkatkan efisiensi dan efektivitas kerja dewan pengurus dan manajemen perusahaan,meningkatkan mutu hubungan board of directors dengan manajemen senior perusahaan (Siswano dan Aldridge, 2008:5).

Pada tahun 2010,Sulistiyowati, Anggaraini, dan Utaminingtyas telah melakukan penelitian dengan judul pengaruh Profitabilitas,Leverage dan Growth terhadapa Kebijakan Dividen dengan Good Corporate Governance sebagai Variabel Intervening. Dengan hasil analisis menunjukkan bahwa dengan analisis regresi berganda tidak ada satupun variabel independen dan variabel kontrol yang secara statistik berpengaruh terhadap kebijakan dividen. Begitu pula dengan pengujian path analysis yang menyatakan bahwa profitabilitas, leverage, dan growth tidak mempunyai pengaruh terhadap kebijakan dividen dengan good corporate governance sebagai variabel intervening.

\section{LANDASAN TEORI DAN PENGEMBANGAN HIPOTESIS}

\section{Good Corporate Governance}

Menurut (Cadbury Commitee of United Kingdom,1922) : "Seperangkat peraturan yang mengatur hubungan antara pemegang saham, pengurus (pengelola) perusahaan, pihak kreditur, pemerintah, karyawan, serta para pemegang kepentingan internal dan eksternal lainnya yang berkaitan dengan hak-hak dan kewajiban mereka atau dengan kata lain suatu sistem yang mengarahkan dan mengendalikan 
perusahaan". (Effendi,2009) dalam bukunya The Power of Good Corporate Governance, pengertian GCG adalah suatu sistem pengendalian internal perusahaan yang memiliki tujuan utama mengelola risiko yang signifikan guna memenuhi tujuan bisnisnya melalui pengamanan aset perusahaan dan meningkatkan nilai investasi pemegang saham dalam jangka panjang. (Agoes,2006), Tata Kelola Perusahaan yang baik adalah : Sistem yang mengatur hubungan peran Dewan Komisaris, peran Direksi, pemegang saham, dan pemangku kepentingan lainnya. Disebut juga sebagai suatu proses yang transparan atas penentuan tujuan perusahaan, pencapaiannya dan penilaian kinerjanya.

\section{Tujuan Good Corporate Governance}

Tujuan penerapan prinsip-prinsip good corporate governance pada Perum Perumnas adalah:

1. Memaksimalkan nilai perusahaan dalam bentuk peningkatan kinerja (high performance) serta citra perusahaan yang baik (good corporate image).

2. Mendorong pengelolaan perusahaan secara profesional, transparan dan efisien serta memberdayakan fungsi dan meningkatkan kemandirian organ perusahaan.

3. Mendorong organ perusahaan dalam membuat keputusan dan menjalankan tindakan dilandasi dengan nilai etika/moral yang tinggi dan kepatuhan terhadap peraturan perundang-undangan yang berlaku, serta kesadaran akan adanya tanggungj awab sosial perusahaan terhadap stakeholders

4. Mendorong pengelolaan sumber daya dan risiko perusahaan secara lebih efisien dan efektif.

5. Mengurangi potensi benturan kepentingan organ perusahaan dan pekerja dalam menjalankan bisnis perusahaan.

\section{Prinsip Good Corporate Governance}

Menurut (Hamdani,2016:72-76) prinsip GCG yaitu transparansi, akuntabilitas, responsibility, independensi serta kewajaran dan kesetaraan diperlukan untuk mencapai kesinambungan usaha (sustainability) perusahaan dengan memperhatikan pemangku kepentingan (stakeholders). Berikut uraian prinsip-prinsip GCG yang berlaku secara umum: 


\section{1) Transparansi (Transparancy)}

Prinsip dasar transparansi menunjukan tindakan perusahaan untuk dapat memberikan informasi yang dibutuhkan oleh seluruh stakeholders. transparansi (transparency) mengandung unsur pengungkapan (disclosure) dan penyediaan informasi secara tepat waktu, memadai, jelas, akurat, dan dapat diperbandingkan serta mudah diakses oleh pemangku kepentingan dan masyarakat.

\section{2) Akuntabilitas (Accountibility)}

Prinsip dasar akuntabilitas (accountability) bagi perusahaan harus dapat mempertanggungjawabkan kinerja nya secara transparan dan wajar. Untuk itu perusahaan harus dikelola secara benar, terukur, dan sesuai dengan kepentingan pemegang saham dan pemangkun kepentingan lain.

\section{3) Responsibilitas (Responsibility)}

Responsibilitas diartikan sebagai tanggung jawab perusahaan sebagai anggota masyarakat untuk mematuhi peraturan yang berlaku dan pemenuhan terhadap kebutuhan-kebutuhan sosial. Prinsip dasar responsibilitas, pada prinsipnya perusahaan harus mematuhi peraturan perundang-undangan serta melaksanakan tanggung jawab terhadap masyarakat dan lingkungan sehingga dapat terpelihara kesinambungan usaha dalam jangka panjang dan mendapat pengakuan sebagai good corporate citizen.

4) Independensi (Independency)

Prinsip dasar independensi dalam pelaksanaan GCG bagi perusahaan diharapkan pengelolaan dapat dilakukan secara independen sehingga masingmasing organ perusahaan tidak saling mendominasi dan tidak dapat diintervensi oleh pihak lain.

5) Kewajaran dan Kesetaraan (Fairness)

Prinsip dasar kewajaran dan kesetaraan dalam melaksanakan kegiatannya, perusahaan harus senantiasa memperhatikan kepentingan pemegang saham dan pemangku kepentingan lainnya berdasarkan asas kewajaran dan kesetaraan. Prinsip kewajaran dan kesetaraan adalah prinsip yang mengandung unsur keadilan, yang menjamin bahwa setiap keputusan dan kebijakan yang 
diambil adalah demi kepentingan seluruh pihak yang berkepentingan termasuk pelanggan, pemasok, pemegang saham, investor serta masyarakat luas.

\section{Manfaat Good Corporate Governance}

Menurut (Sukrisno Agoes \& I Cenik Ardana,2013:106) bahwa manfaat good corporate governance adalah:

1) Memudahkan akses terhadap investasu domestik maupun asing

2) Mendapatkan biaya modal (cost of capital) yang lebih murah

3) Memberikan keputusan yang lebih baik dalam meningkatkan kinerja ekonomi perusahaan

4) Meningkatkan keyakinan dan kepercayaan dari para pemangku kepentingan terhadap perusahaan

5) Melindungi direksi dan komisaris dari tuntutan hukum.

\section{Kebijakan Dividen}

Pengertian kebijakan dividen adalah keputusan direksi apakah laba yang dihasilkan perusahaan pada akhir periode dibagikan kepada para pemilik saham (dividen) atau laba tersebut ditahan sebagai penambah modal perusahaan yang akan digunakan dalam kegiatan, atau investasi pengembangan perusahaan dimasa mendatang.(Bambang Riyanto,2001:281) mendefinisikan kebijakan dividen sebagai "politik yang bersangkutan dengan penentuan pembagian pendapatan (earning) antara penggunaan pendapatan untuk dibayarkan kepada para pemegang saham sebagai dividen atau untuk digunakan di dalam perusahaan (laba ditahan).Menurut (Sundjaja \& Barlian,2003: 390) kebijakan dividen adalah rencana tindakan yang harus diikuti dalam membuat keputusan dividen.

\section{Faktor-faktor yang mempengaruhi kebijakan dividen}

Menurut (Riyanto,2008:267),faktor-faktor yang mempengaruhi kebijakan dividen suatu perusahaan adalah sebagai berikut :

1. Posisi Likuiditas Perusahaan

Posisi kas atau likuiditas dari suatu perusahaan merupakan faktor yang penting yang harus dipertimbangkan sebelum mengambil keputusan untuk menetapkan besarnya dividen yang akan dibayarkan kepada para pemegang saham.

2. Kebutuhan Dana untuk Membayar Hutang 
Apabila perusahaan menetapkan bahwa pelunasan utangnya akan diambilkan dari laba ditahan, berarti perusahaan harus menahan sebagian besar dari pendapatannya untuk keperluan tersebut, yang ini berarti bahwa hanya sebagian kecil saja dari pendapatan atau earning yang dapat dibayarkan sebagai dividen. Dengan kata lain perusahaan harus menetapkan dividen payout ratio yang rendah.

3. Tingkat Pertumbuhan Perusahaan

Makin cepat tingkat pertumbuhan suatu perusahaan, makin besar kebutuhan akan dana untuk membiayai pertumbuhan perusahaan tersebut. Makin besar kebutuhan dana untuk waktu mendatang untuk membiayai pertumbuhannya, perusahaan tersebut biasanya lebih senang untuk menahan earningnya daripada dibayarkan sebagai dividen kepada para pemegang saham dengan mengingat batasan-batasan biayanya.

4. Pengawasan terhadap Perusahaan

Pada pembelanjaan intern dalam rangka usaha mempertahankan "control" terhadap perusahaan, berati mengurangi "dividen payout ratio"nya.

\section{Likuiditas}

Menurut (Syamsuddin ,2001 : 41 ) menyatakan bahwa likuiditas merupakan indikator mengenai kemampuan perusahaan untuk membayar semua kewajiban finansial jangka pendek pada saat jatuh tempo dengan menggunakan aktiva lancar yang tersedia. Likuiditas tidak hanya berkaitan dengan keadaan keseluruhan keuangan perusahaan, tetapi juga berkaitan dengan kemampuannya untuk mengubah aktiva lancar tertentu menjadi uang kas.(Munawir,2004:31) menyatakan bahwa likuiditas adalah menunjukan kemampuan suatu perusahaan untuk memenuhi kewajiban keuangannya yang harus segera dipenuhi, atau kemampuan perusahaan untuk memenuhi kewajiban keuangan pada saat ditagih.Menurut (Riyanto,2010:25)menyatakan bahwa :"likuiditas adalah berhubungan dengan masalah kemampuan suatu perusahaan untuk memenuhi kewajiban finansialnya yang segera harus dipenuhi. Jumlah alat-alat pembayaran (alat-alat likuid) yang dimiliki oleh suatu perusahaan pada suatu saat merupakan kekuatan membayar dari perusahaan yang bersangkutan". 


\section{Jenis-Jenis Likuiditas}

Likuiditas merupakan rasio yang digunakan untuk mengukur tingkat pengembalian kewajiban lancar pada perusahaan. Likuiditas umumnya diukur dengan perbandingan antara aktiva lancar dengan hutang lancar yang disebut rasio lancar atau current ratio. Namun tidak semua perusahaan yang menggunakan rasio tersebut. sebab rasio likuiditas memiliki beberapa alat ukur, seperti Quick ratio, Cash ratio.

\section{Manfaat Likuiditas}

Rasio Likuiditas mempunyai manfaat besar bagi perusahaan, yang menyebabkan rasio ini paling sering di pakai perusahaan dan rasio ini tidak ada ketentuan yang mutlak tentang berapa tingkat yang di anggap baik atau yang harus dipertahankan oleh suatu perusahaan karena biasanya tingkat rasio ini juga sangat tergantung kepada jenis usaha dari masing- masing perusahaan. Menurut (S. Munawir 2007:71) menyatakan bahwa: "rasio yang digunakan untuk menganalisa dan menginter-pretasikan posisi keuangan jangka pendek, tetapi juga sangat membantu bagi management untuk mengecek efisiensi modal kerja yang digunakan dalam perusahaan. Juga penting bagi kreditor jangka panjang dan pemegang saham yang akhirnya atau setidak- tidaknya ingin mengetahui prospek dari deviden dan pembayaran bunga di masa yang akan datang”.

Menurut (Kasmir 2012:132) adapun tujuan dan manfaat dari Rasio likuiditas yaitu, sebagai berikut :

1) Untuk mengukur kemampuan perusahaan membayar kewajiban atau utang yang segera jatuh tempo pada saat ditagih.

2) Untuk mengukur kemampuan perusahaan membayar kewajiban jangka pendek dengan aktiva lancar secara keseluruhan.

3) Untuk mengukur kemampuan perusahaan membayar kewajiban jangka pendek dengan aktiva lancar tanpa memperhitungkan sediaan atau piutang.

4) Untuk mengukur atau membandingkan antara jumlah sediaan yang ada dengan modal kerja perusahaan.

5) Untuk mengukur seberapa besar uang kas yang tersedia untuk membayar utang.

6) Sebagai alat perencanaan ke depan, terutama yang berkaitan dengan perencanaan kas dan utang. 
7) Untuk melihat kondisi dan posisi likuiditas perusahaan dari waktu ke waktu dengan membandingkannya untuk beberapa periode.

8) Untuk melihat kelemahan yang dimiliki perusahaan dari masing- masing komponen yang ada di aktiva lancar dan hutang lancar.

9) Menjadi alat pemicu bagi pihak manajemen untuk memperbaiki kinerjanya, dengan melihat rasio likuiditas yang ada pada saat ini.

\section{Faktor-faktor Yang Mempengaruhi Likuiditas}

Likuiditas merupakan kemampuan suatu perusahaan untuk memenuhi kewajiban keuangannya dalam jangka pendek atau yang segera dibayar. Alat pemenuhan kewajiban keuangan jangka pendek ini berasal dari unsur-unsur aktiva yang bersifat likuid, yakni aktiva lancar dengan perputaran kurang dari satu tahun, karena lebih mudah dicairkan daripada ktiva tetap yang perputarannya lebih dari satu tahun. Menurut (Hani 2015:121) menyatakan bahwa "faktor-faktor yang dapat mempengaruhi likuiditas adalah unsur pembentuk likuiditas itu sendiri yakni bagian dari aktiva lancar dan kewajiban lancar, termasuk perputaran kas, dan arus kas operasi, ukuran perusahaan, kesempatan bertumbuh (growth opportunities), keragaman arus kas operasi, rasio utang atau struktur utang."

\section{Free Cash Flow}

Menurut (PSAK No.2 2004:5) menjelaskan mengenai definisi dari arus kas adalah: "Arus kas masuk dan arus kas keluar adalah investasi yang sifatnya sangat liquid, berjangka pendek dan dengan cepat dapat dijadikan kas dalam jumlah tertentu tanpa menghadapi resiko perubahan nilai yang signifikan. Aliran kas bebas atau lebih sering dikenal dengan free cash flow dapat diartikan aliran kas yang tersedia untuk dibagikan kepada para pemegang saham atau pemilik setelah perusahaan melakukan investasi pada fixed asset (aktiva tetap) dan working capital (modal kerja) yang diperlukan untuk kelangsungan usahanya. Dengan kata lain, free cash flow adalah kas yang tersedia di atas kebutuhan investasi yang menguntungkan (Sartono, 2001).

\section{Manfaat Free Cash Flow}

Free Cash Flow mempunyai manfaat bagi pemegang saham atau pemilik dan manajer. Manfaat bagi pemegang saham adalah free cash flow akan dibagikan dalam bentuk dividen. Dividen merupakan bentuk keuntungan yang secara langsung dapat 
meningkatkan kesejahteraan pemegang saham, oleh karena itu pembagian dividen sangat diharapkan oleh pemegang saham. Besar kecilnya jumlah dividen yang diterima oleh pemegang saham proporsional dengan jumlah kepemilikan pemegang saham dalam perusahaan dalam bentuk lembar saham.

Beberapa manfaat free cash flow bagi manajer selaku pengelola perusahaan antara lain:

1. Free cash flow dapat digunakan untuk mendanai kegiatan investasi perusahaan yang mempunyai net present value positif (Rose et al, 2005).

2. Manajer dapat menggunakan free cash flow untuk membiayai fasilitas-fasilitas seperti fasilitas kantor dan fasilitas pribadi (Karsana dan Supriyadi, 2005).

3. Free cash flow dapat digunakan untuk menambah investasi dalam perusahaan dalam bentuk laba yang ditahan.

4. Pemegang saham dan manajer selalu menghendaki agar free cash flow yang dihasilkan perusahaan selalu meningkat dari tahun ke tahun kerena dengan adanya peningkatan free cash flow yang dihasilkan akan sejalan dengan meningkatnya kesejahteraan dan manfaat yang akan diperoleh baik bagi pemegang saham maupun bagi manajer.

\section{Hipotesis Penelitian}

Likuiditas perusahaan diasumsikan dalam penelitian ini mampu menjadi alat prediksi tingkat pengembalian investasi berupa dividen bagi investor. Current ratio seringkali dijadikan sebagai ukuran likuiditas, termasuk dalam persyaratan kontrak kredit. Penelitian (Suharli dan Oktorina,2005) menunjukkan bahwa likuiditas memiliki hubungan yang positif dengan kebijakan dividen. Penelitian mengenai free cash flow dengan kebijakan dividen di Indonesia dilakukan oleh (Nurdiana,2007) dan (Yunita,2008) yang menemukan bahwa free cash flow, memiliki pengaruh yang signifikan terhadap kebijakan dividen. (Gugler,2003) yang menyatakan bahwa corporate governance sebagai penentu besarnya kebijakan dividen. Perusahaan yang melaksanakan corporate governance dapat mendatangkan pertambahan yang signifikan untuk dividend to cash flow ratio (Kowalewski et al, 2007). Hal ini juga sejalan dengan (Jiraporn, et al,2008) yang menyatakan bahwa perusahaan dengan kualitas yang baik akan membayarkan dividen yang lebih besar. Namun pada penelitian Black, et al (dalam Siallagan \& Machfoedz, 2007) dimana tidak 
ditemukannya bukti bahwa perusahaan dengan corporate governance yang baik lebih menguntungkan atau membayar dividen yang lebih tinggi.

Hipotesis adalah jawaban sementara atau jawaban teoritis terhadap pertanyaan-pertanyaan yang dikemukakan dalam perumusan masalah. Berdasarkam kosep penelitian yang telah dikemukaakan penulis diatas,maka hipotesis yang dikemukakan adalah sebagai berikut :

$\mathrm{H}_{1} \quad$ :Terdapat pengaruh Likuiditas terhadap kebijakan dividen

$\mathrm{H}_{2}$ :Terdapat pengaruh Free Cash Flow terhadap kebijakan dividen

$\mathrm{H}_{3}$ :Terdapat pengaruh Likuiditas dan Free Cash flow terhadap kebijakan deviden dengan Good Corporate Governance sebagai variable intervening.

\section{METODE PENELITIAN}

\section{Populasi dan Sampel}

Menurut (Sugiyono,2003:73) populasi adalah wilayah generalisaasi yang terdiri atas obyek atau subyek yang mempunyai kualitas dan karakteristik tertentu yang ditetapkan oleh peneliti untuk dipelajari dan kemudian ditarik kesimpulanya. Populasi dalam penelitian ini adalah data publikasi pada Perushaaan Manufaktur pada bidang Perdaggangan dan Perindustrian di Bursa Efek Indonesia dan Semua perusahaan yang masuk dalam pemeringkatan pada CGPI (Corporate Governance Perception Index) pada tahun 2016,2017 dan 2018. Menurut (Sugiyono,2008 :116) "Sampel adalah bagian dari jumlah dan karakteristik yang dimiliki populasi tersebut".Sampel yang digunakan dalam penelitian ini adalah perusahaan manufaktur yang bergerak dalam bidang perdaggangan dan perindustrian yang masuk dalam pemeringkatan Corporate Governance Perception Index (CGPI) yang dilakukan oleh The Indonesian Institute for Corporate Governance (IICG) tahun 2016,2017 dan 2018 serta menerbitkan laporan keuangan per 31 Desember. Penelitian ini menggunakan metode penggabungan (pooled data untuk tahun 2016,2017 dan 2018).

\section{Jenis Dan Metode Pengumpulan Data}

Data laporan keuangan, dividen, likuiditas, dan free cash flow, bersumber dari laporan keuangan perusahaan yang dipublikasikan di Bursa Efek Indonesia dan situs resmi perusahaan sampel. Sedangkan data implementasi good corporate governance menggunakan hasil riset dan pemeringkatan Corporate Governance Perception Index 
(CGPI) yang dilakukan oleh The Indonesian Institute for Corporate Governance (IICG) pada tahun 2016,2017 dan 2018.

\section{Teknik Analisis Data}

Penelitian ini menggunakan analisis Regresi Berganda.Dalam regresi berganda digunakan untuk mengetahui apakah hipotesis penelitian terbukti signifikan atau tidak signifikan. Peneliti menggunakan SPSS versi 16 untuk uji analisis Regresi Berganda. Adapun persamaan sebagai berikut sebelum melakukan analisis regresi berganda:

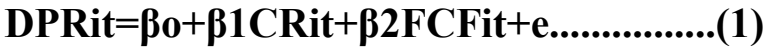

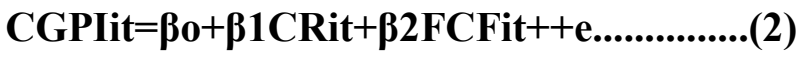

\section{HASIL DAN PEMBAHASAN}

\section{Analisis Deskriptif}

Variabel dependen dalam penelitian ini adalah kebijakan dividen dan variabel independen dalam penelitian ini adalah likuiditas dan free cash flow sedangkan variabel intervening nya adalah good corporate governance.

Berikut ini peneliti sajikan hasil tabulasi data dari perhitungan untuk beberapa variabel diatas dari tahun 2016-2018:

\begin{tabular}{|c|c|c|c|c|c|c|c|c|c|c|c|c|}
\hline \multicolumn{13}{|c|}{ Tabel 4.3.Hasil Perhitungan Dividend Payouut Ratio (DPR) Perusahaan Sampel Tahun 2016,2017.2018: } \\
\hline \multirow{2}{*}{$\begin{array}{c}\text { Kode } \\
\text { Perusahaan }\end{array}$} & \multicolumn{4}{|c|}{2016} & \multicolumn{4}{|c|}{2017} & \multicolumn{4}{|c|}{2018} \\
\hline & Dividen & Laba Bersih & DPR $(\%$ & Kategori & Dividen & Laba Bersih & DPR (\%) & Kategori & Dividen & Laba Bersih & DPR $(\%) \mid K$ & Kategori \\
\hline PTBA & 610,733 & $1,672,578$ & $36 \%$ & Rendah & 611,822 & 4,271,977 & $14 \%$ & Rendah & $3,391,860$ & 4,864,747 & $69 \%$ & Tinggi \\
\hline TINS & 30,476 & 340,752 & $8.94 \%$ & Rendah & 75,550 & 323,247 & $23 \%$ & Rendah & 175,846 & 250,522 & $70 \%$ & Tinggi \\
\hline WIKA & $446,774,397$ & $717,337,544$ & $62 \%$ & Sedang & $344,663,064$ & $366,680,402$ & $94 \%$ & Sangat Tinggi & $303,147,996$ & $418,070,823$ & $72 \%$ & Tinggi \\
\hline ELSA & 76,241 & 393,611 & $19 \%$ & $\begin{array}{l}\text { Sangat } \\
\text { Rendah }\end{array}$ & 31,687 & 337,087 & $9.40 \%$ & $\begin{array}{l}\text { Sangat } \\
\text { Rendah }\end{array}$ & 37,154 & 461,913 & $8.40 \%$ & $\begin{array}{l}\text { Sangat } \\
\text { Rendah }\end{array}$ \\
\hline SMBR & $88,539,107$ & $223,383,610$ & $40 \%$ & Rendah & $64,768,605$ & $124,563,559$ & $51 \%$ & Sedang & $36,661,210$ & $60,367,810$ & $61 \%$ & Sedang \\
\hline SMSM & 71,983 & 619,931 & $12 \%$ & $\begin{array}{l}\text { Sangat } \\
\text { Rendah }\end{array}$ & 329,205 & 499,927 & $65 \%$ & Tinggi & 315,713 & 593,309 & $52 \%$ & Sedang \\
\hline TCID & $82,437,333,470$ & $366,927,000,000$ & $22 \%$ & $\begin{array}{l}\text { Sangat } \\
\text { Rendah }\end{array}$ & $82,437,333,470$ & $161,364,000,000$ & $51 \%$ & Sedang & $82,437,333,470$ & $123,546,000,000$ & $66 \%$ & Tinggi \\
\hline ASGR & 125,437 & 333,546 & $37 \%$ & Rendah & 66,090 & 243,085 & $27 \%$ & Rendah & 68,788 & 266,747 & $25 \%$ & $\begin{array}{l}\text { Sangat } \\
\text { Rendah }\end{array}$ \\
\hline AMFG & 34,720 & 431,879 & $8.90 \%$ & $\begin{array}{l}\text { Sangat } \\
\text { Redah }\end{array}$ & 34,720 & 40,141 & $86 \%$ & Sangat Tinggi & 13,020 & 16,779 & $77 \%$ & Tinggi \\
\hline ASII & 8,144 & 10,244 & $79 \%$ & Tinggi & $94,035,304,967$ & $286,117,906,103$ & $32 \%$ & Rendah & $103,083,063,043$ & $1,996,060,000,000$ & $51 \%$ & Sedang \\
\hline UNTR & $1,657,259$ & $5,473,204$ & $30 \%$ & Rendah & $2,544,232$ & $6,299,986$ & $40 \%$ & Rendah & $3,883,845$ & $10,145,030$ & $38 \%$ & Rendah \\
\hline MLTA & $24,496,404$ & $312,346,269$ & $7.80 \%$ & Rendah & $40,572,169$ & $418,581,893$ & $9.60 \%$ & $\begin{array}{l}\text { Sangat } \\
\text { Rendah }\end{array}$ & $72,364,112$ & $393,348,298$ & $18 \%$ & $\begin{array}{l}\text { Sangat } \\
\text { Rendah }\end{array}$ \\
\hline ASSA & $13,590,000,000$ & $44,604,904,088$ & $30 \%$ & Rendah & $23,782,500,000$ & $85,126,757,813$ & $27 \%$ & Rendah & $40,770,000,000$ & $123,171,145,486$ & $33 \%$ & Rendah \\
\hline
\end{tabular}


Dari hasil perhitungan dan tabulasi data diatas dapat dilihat dan disimpulkan oleh peneliti bahwa kebijakan dividen mengalami beberapa situasi yaitu :

a) Sebanyak 6 perusahaan yaitu PT Bukit Asam Tbk,PT Timah Tbk, PT Wijaya Karya Tbk, PT Semen Batubara Tbk,PT Mandom Indonesia Tbk dan PT Asahimas Flat Glass Tbk mengalami peningkatan kebijakan dividen dari tahun ke tahun.

b) Sebanyak 3 perusahaan yaitu PT Elnusa Tbk,PT United Tractors Tbk dan PT Adi Sarana Armada Tbk berada pada kondisi stabil,artinya tidak mengalami peningkatan maupun penurunan untuk kebijakan dividenya dari tahun ke tahun.

c) Sebanyak 4 perusahaan yaitu PT Selamat Sempurna Tbk,PT Astra Graphia Tbk,PT Astra Internasional Tbk dan PT Metropolitan Land Tbk yang mengalami penurunan dalam pembagian dividenya dari tahun ke tahun.

Kebijakan dividen tertinggi ada pada tahun 2017 yaitu sebesar 94\% pada perusahaan Wijaya Karya Tbk,dan kebijakan dividen terendah ada pada tahun 2016 sebesar $12 \%$ pada perusahaan Selamat Sempurna.Hal ini menunjukan bahwa kebijakan dividen dalam suatu perusahaan mengalami peningkatan,penurunan dan stabil setiap tahunya.Ini dikarenakan pembagian dividen dalam suatu perusahaan dapat berubah sesuai dengan jumlah laba bersih yang diterima perusahaan setiap tahunya.Dimana semakin tinggi jumlah laba bersihnya,maka semakin banyak juga jumlah dividen yang akan dibagikan.

\begin{tabular}{|c|c|c|c|c|c|c|c|c|c|c|c|c|}
\hline \multicolumn{13}{|c|}{ Hasil Perhitungan Likuiditas Perusahaan Sampel tahun $2016,2017,2018$ : } \\
\hline \multirow[b]{2}{*}{$\begin{array}{l}\text { Kode } \\
\text { Perusahaan }\end{array}$} & \multicolumn{4}{|c|}{2016} & \multicolumn{4}{|c|}{2017} & \multicolumn{4}{|c|}{2018} \\
\hline & AKTIVA LANCAR & HUTANG LANCAR & CR (\%) & Kategori & AKTIVA LANCAR & HUTANG LANCAR & CR (\%) & Kategori & AKTIVA LANCAR & HUTANG LANCAR & CR (\%) & Kategori \\
\hline PTBA & 8.349 .927 & 8.024 .369 & $104,05 \%$ & $\begin{array}{c}\text { Cukup } \\
\text { Baik }\end{array}$ & 11.117 .745 & 8.187 .497 & $126,09 \%$ & $\begin{array}{c}\text { Cukup } \\
\text { Baik }\end{array}$ & 11.739 .344 & 7.903.237 & $148,53 \%$ & $\begin{array}{c}\text { Cukup } \\
\text { Baik }\end{array}$ \\
\hline TINS & 5.237.907 & 3.894 .946 & $134,79 \%$ & $\begin{array}{c}\text { Cukup } \\
\text { Baik }\end{array}$ & 6.996 .966 & 5.814 .816 & $120,32 \%$ & $\begin{array}{c}\text { Cukup } \\
\text { Baik }\end{array}$ & 9.204 .287 & 8.596 .067 & $107,07 \%$ & $\begin{array}{c}\text { Cukup } \\
\text { Baik }\end{array}$ \\
\hline WIKA & 21.552.497.929 & 18.597.824.186 & $115,88 \%$ & $\begin{array}{c}\text { Cukup } \\
\text { Baik }\end{array}$ & 34.910 .108 .265 & 31.051 .949 .689 & $112,42 \%$ & $\begin{array}{c}\text { Cukup } \\
\text { Baik }\end{array}$ & 43.555.495.865 & 42.014.686.674 & $103,66 \%$ & $\begin{array}{c}\text { Cukup } \\
\text { Baik }\end{array}$ \\
\hline ELSA & 1.865 .116 & 1.313.213 & $142,02 \%$ & $\begin{array}{c}\text { Cukup } \\
\text { Baik }\end{array}$ & 2.379 .465 & 1.803 .449 & $131,93 \%$ & $\begin{array}{c}\text { Cukup } \\
\text { Baik } \\
\end{array}$ & 3.158 .507 & 2.357.127 & $133,93 \%$ & $\begin{array}{c}\text { Cukup } \\
\text { Baik } \\
\end{array}$ \\
\hline SMBR & 838.232 .034 & 1.248.119.294 & $67,15 \%$ & $\begin{array}{c}\text { Kurang } \\
\text { Baik }\end{array}$ & 1.123 .602 .449 & 1.647 .477 .388 & $68,20 \%$ & $\begin{array}{c}\text { Kurang } \\
\text { Baik }\end{array}$ & 1.358 .329 .865 & 2.064 .408 .447 & 65,79 & $\begin{array}{c}\text { Kurang } \\
\text { Baik }\end{array}$ \\
\hline SMSM & 1.454.387 & 674.685 & $215,56 \%$ & $\begin{array}{c}\text { Sangat } \\
\text { Baik }\end{array}$ & 1.570 .110 & 615.157 & $255,23 \%$ & $\begin{array}{c}\text { Sangat } \\
\text { Baik }\end{array}$ & 1.853 .782 & 650.926 & $284,79 \%$ & $\begin{array}{c}\text { Sangat } \\
\text { Baik }\end{array}$ \\
\hline TCID & 1.174.482.404.487 & 401.942.530.776 & $292,20 \%$ & $\begin{array}{c}\text { Sangat } \\
\text { Baik }\end{array}$ & 1.276.478.591.542 & 503.480 .853 .006 & $253,35 \%$ & $\begin{array}{c}\text { Sangat } \\
\text { Baik }\end{array}$ & 1.333 .428 .311 .186 & 472.680 .346 .662 & $282,09 \%$ & $\begin{array}{c}\text { Sangat } \\
\text { Baik }\end{array}$ \\
\hline ASGR & 1.241 .982 & 557.158 & 222,91 & $\begin{array}{c}\text { Sangat } \\
\text { Baik }\end{array}$ & 1.902 .849 & 1.090 .688 & $174,46 \%$ & Baik & 1.764 .349 & 787.113 & $224,15 \%$ & $\begin{array}{c}\text { Sangat } \\
\text { Baik }\end{array}$ \\
\hline AMFG & 1.787 .723 & 1.905 .626 & $93,81 \%$ & $\begin{array}{c}\text { Kurang } \\
\text { Baik }\end{array}$ & 2.003.321 & 2.718 .939 & $73,68 \%$ & $\begin{array}{c}\text { Kurang } \\
\text { Baik }\end{array}$ & 2.208.918 & 4.835 .966 & $45,67 \%$ & Buruk \\
\hline ASII & 110.403 & 121.949 & $90,53 \%$ & $\begin{array}{c}\text { Kurang } \\
\text { Baik }\end{array}$ & 24.817.671.201.079 & 22.463 .030 .586 .953 & $110,48 \%$ & $\begin{array}{c}\text { Cukup } \\
\text { Baik }\end{array}$ & 25.429.544.388.000 & 23.833.342.873.624 & $106,69 \%$ & $\begin{array}{c}\text { Cukup } \\
\text { Baik }\end{array}$ \\
\hline |UNTR & 42.197.323 & 21.369 .286 & $197,46 \%$ & Baik & 51.202 .200 & 34.734 .168 & $141,47 \%$ & $\begin{array}{c}\text { Cukup } \\
\text { Baik }\end{array}$ & 55.561 .808 & 59.230 .338 & $90,80 \%$ & $\begin{array}{c}\text { Kurang } \\
\text { Baik }\end{array}$ \\
\hline MLTA & 2.172.521.190 & 1.430 .126 .743 & $151,19 \%$ & Baik & 2.626.968.671 & 1.819 .793 .556 & $144,35 \%$ & $\begin{array}{c}\text { Cukup } \\
\text { Baik }\end{array}$ & 2.775 .577 .932 & 1.755.200.333 & $153,13 \%$ & Baik \\
\hline ASSA & 292.211 .049 .808 & 2.126 .179 .428 .075 & $7,20 \%$ & Buruk & 343.676 .979 .857 & 2.321 .587 .255 .114 & $14,80 \%$ & Buruk & 536.760 .828 .132 & 2.924.124.201.613 & $18,35 \%$ & Buruk \\
\hline
\end{tabular}


Dari hasil perhitungan dan tabulasi data diatas dapat dilihat dan disimpulkan oleh peneliti bahwa likuiditas mengalami beberapa situasi yaitu :

a) Sebanyak 4 perusahaan yaitu PT Bukit Asam Tbk,PT Timah Tbk,PT Wijaya Karya Tbk,PT Elnusa Tbk berada dalam posisi stabil dengan kategori cukup baik.

b) Sebanyak 3 perusahaan yaitu PT Selamat Sempurna Tbk,PT Mandom Indonesia Tbk dan PT Astra Graphia Tbk yang berada pada posisi stabil degan kategori sangat baik.

c) PT Astra Internasional Tbk dan Pt Metropolitan Land mengalami peningkatan dari tahun ke tahunya.

d) PT Asahimas Flat Glass Tbk dan PT United Tractors Tbk mengalami penurunan dari tahun ke tahunya.

e) Ada 1 perusahaan yaitu PT Adi Sarana Armada Tbk yang likuiditasnya mengalami keadaan stabil dengan kategori buruk.

Tingkat likuiditas tertinggi ada pada perusahaan PT Selamat Sempurna Tbk dengan presentasi $284,79 \%$ pada tahun 2018 dan tingkat likuiditas terendah pada PT Adi Sarana Armada Tbk degan tingkat presentasinya 7,20\% pada tahun 2016. Hal ini menunjukan bahwa tingkat likuiditas dalam suatu perusahaan mengalami peningkatan,penurunan dan stabil dari tahun ke tahunya. Hal ini tergantung pada jumlah aktiva lancar yang dapat diperoleh dalam suatu perusahaan dan juga total hutang lancar dalam suatu perusahaan.

\begin{tabular}{|c|c|c|c|c|c|c|c|c|c|c|c|c|}
\hline \multicolumn{13}{|c|}{ Hasil Perhitungan Free Cash Flow pada Perusahaan Sampel tahun 2016,2017,2018 } \\
\hline \multirow{2}{*}{$\begin{array}{c}\text { Kode } \\
\text { Perusahaan }\end{array}$} & \multicolumn{4}{|c|}{2016} & \multicolumn{4}{|c|}{2017} & \multicolumn{4}{|c|}{2018} \\
\hline & FCF & TOTAL ASSET & FCF (\%) & Kategori & FCF & TOTAL ASSET & FCF (\%) & Kategori & FCF & TOTAL ASSET & FCF $(\%)$ & Kategori \\
\hline PTBA & $1,635,000$ & $18,576,774$ & $8.80 \%$ & Baik & $1,738,258$ & $21,987,482$ & $7.90 \%$ & Baik & $7,082,212$ & $24,172,933$ & $2.90 \%$ & $\begin{array}{c}\text { Kurang } \\
\text { Baik }\end{array}$ \\
\hline TINS & 555,344 & $9,548,631$ & $5.81 \%$ & Baik & $-631,145$ & $11,876,309$ & $-5.30 \%$ & Buruk & 242,029 & $15,117,948$ & $1.60 \%$ & $\begin{array}{c}\text { Kurang } \\
\text { Baik }\end{array}$ \\
\hline WIKA & $834,549,571$ & $31,096,539,490$ & $2.68 \%$ & $\begin{array}{c}\text { Kurang } \\
\text { Baik }\end{array}$ & $888,479,173$ & $45,683,774,302$ & $1.94 \%$ & $\begin{array}{c}\text { Kurang } \\
\text { Baik }\end{array}$ & $1,474,874,348$ & $59,230,001,239$ & $2.40 \%$ & $\begin{array}{c}\text { Kurang } \\
\text { Baik }\end{array}$ \\
\hline ELSA & 185,657 & $4,190,956$ & $4.44 \%$ & $\begin{array}{c}\text { Kurang } \\
\text { Baik }\end{array}$ & 116,103 & $4,855,369$ & $2.30 \%$ & $\begin{array}{c}\text { Kurang } \\
\text { Baik }\end{array}$ & $-194,439$ & $5,657,327$ & $-3.40 \%$ & Buruk \\
\hline SMBR & $-1,796,006,421$ & $4,368,876,996$ & $-4.12 \%$ & Buruk & $-196,253,325$ & $5,060,337,247$ & $-3.80 \%$ & Buruk & $-150,203,025$ & $5,538,079,503$ & $-2.70 \%$ & Buruk \\
\hline SMSM & 511,395 & $2,254,740$ & $22.68 \%$ & $\begin{array}{c}\text { Sangat } \\
\text { Baik }\end{array}$ & 380,427 & $2,443,341$ & $15 \%$ & $\begin{array}{l}\text { Sangat } \\
\text { Baik }\end{array}$ & 399,489 & $2,801,203$ & $14.26 \%$ & $\begin{array}{c}\text { Sangat } \\
\text { Baik }\end{array}$ \\
\hline TCID & $|127,558,350,178|$ & $2,185,101,036,101$ & $5.80 \%$ & Baik & $-17,174,245,633$ & $2,082,096,848,703$ & $1.20 \%$ & $\begin{array}{c}\text { Kurang } \\
\text { Baik }\end{array}$ & $127,558,350,178$ & $2,185,101,038,101$ & $5.80 \%$ & Baik \\
\hline ASGR & 7,625 & $1,723,468$ & $0.44 \%$ & Buruk & 520,026 & $2,411,872$ & $22 \%$ & $\begin{array}{c}\text { Sangat } \\
\text { Baik }\end{array}$ & 221,742 & $2,271,344$ & $9.70 \%$ & Baik \\
\hline AMFG & $-1,270,189$ & $5,504,890$ & $-23.07 \%$ & Buruk & $-1,697,851$ & $6,267,816$ & $-27 \%$ & Buruk & $-718,567$ & $8,432,632$ & $-8.50 \%$ & Buruk \\
\hline ASII & 13,435 & 261,855 & $5.13 \%$ & Baik & $3,041,982,990,922$ & $28,332,948,012,950$ & $10 \%$ & $\begin{array}{c}\text { Sangat } \\
\text { Baik }\end{array}$ & $-76,713,915,771$ & $30,118,614,769,882$ & $-0.20 \%$ & Buruk \\
\hline UNTR & $7,453,269$ & $63,991,229$ & $11.64 \%$ & $\begin{array}{c}\text { Sangat } \\
\text { Baik }\end{array}$ & $5,455,002$ & $82,262,093$ & $6.60 \%$ & Baik & $9,169,766$ & $116,281,017$ & $7.80 \%$ & Baik \\
\hline MLTA & $253,836,773$ & $3,932,529,273$ & $6.40 \%$ & Baik & $52,340,902$ & $4,819,145,802$ & $10 \%$ & $\begin{array}{c}\text { Sangat } \\
\text { Baik }\end{array}$ & $500,217,605$ & $5,193,962,740$ & $9.60 \%$ & Baik \\
\hline ASSA & $\mid 160,937,932,071$ & $3,029,807,463,353$ & $5.10 \%$ & Baik & $63,367,648,252$ & $3,307,396,918,555$ & $1.90 \%$ & $\begin{array}{c}\text { Kurang } \\
\text { Baik }\end{array}$ & $9,396,331,569$ & $4,062,536,132,739$ & $0.20 \%$ & Buruk \\
\hline
\end{tabular}


Dari hasil perhitungan dan tabulasi data diatas dapat dilihat dan disimpulkan oleh peneliti bahwa free cash fllow mengalami beberapa situasi yaitu :

a) Sebanyak 4 perusahaan yaitu PT Mandom Indonesia Tbk,PT Astra Graphia Tbk,PT Astra Indonesia Tbk dan PT Metropolitan Land Tbk mengalami peningkatan dalam free cash flow dari tahun ke tahun.

b) Terdapat 4 perusahan yang tidak mengalami peningkatan maupun penurunan free cash flow dari tahun ke tahun atau dengan kata lain free cash flow nya nya stabil dari tahun ke tahun dengan kategori sebagai berikut yaitu PT Wijaya Karya Tbk dengan kategori Buruk,PT Semen Baturaja Tbk dengan kategori Baik,PT Asahimas Flat Glass Tbk dengan kategori baik dan PT Selamat Sempurna dengan kategori sangat baik.

c) Ada 5 perusahaanyaitu PT Bukit Asam Tbk,PT Timah Tbk,PT Elnusa Tbk,PT United Tractors tbk dan PT Adi sarana Armada Tbk yang free cash flownya mengalami penurunan dari tahun ke tahun.

Perusahaan dengan tingkat free cash flow tertinggi ada pada perusahaan PT Selamat Sempurna Tbk pada tahun 2016 dengan tingkat presentasiya adalah 22,68\%,dan free cash flow terendah ada pada PT Asahimas Flat Glass Tbk dengan presentasinya adalah $-23,07 \%$. Hal ini menunjukan bahwa tingkat free cash flow dalam suatu perusahaan mengalami peningkatan,penurunan dan stabil dari tahun ke tahunya.Hal ini tergantung pada jumlah total kas dari aktivitas operasi yang dapat diperoleh dalam suatu perusahaan dan juga total pengeluaran untuk pembelian asset tetapnya.

\section{Analisis Regresi Linear Berganda}

Berdasarkan hasil Uji Parsial t, dapat kita menarik suatu model persamaan regresi sebagai berikut:

$$
\begin{gathered}
\text { DPR }=8.793+0,67 \mathrm{CR}-0,98 \mathrm{FCF}+0,137 \mathrm{GCG}+0,00 \\
\text { CGPI }=10.239-164 \mathrm{CR}-271 \mathrm{CGC}
\end{gathered}
$$

Konstanta sebesar 8.793 menunjukan bahwa variabel independen dianggap konstan maka rata-rata DPR per perusahaan sebesar 8.793.Koefisien CR (likuiditas) sebesar 0,67 menunjukan bahwa setiap penambahan nilai CR sebesar 1,akan meningkatkan nilai DPR sebesar 0,67.Koefisien FCF (Free Cash Flow) sebesar 0,098 menunjukan bahwa setiap penambahan nilai FCF sebesar 1, akan menurunkan 
akan menurunkan nilai DPR sebesar 0,098.Koefisien GCG (Good Corporate Governance) sebesar 0.137 menunjukan bahwa setiap penambahan nilai GCG sebesar 1, akan meningkatkan nilai DPR sebesar 0,137.

\section{Pengaruh Likuiditas terhadap Kebijakan Dividen}

Berdasarkan hasil pengolahan data diperoleh koefisien regresi likuiditas 0,105 dan tingkat signifikan 0,805, dengan menggunakan alat ukur current ratio. Hal tersebut menunjukkan bahwa rasio likuiditas tidak mempunyai pengaruh terhadap kebijakan dividen. Sejalan dengan penelitian Fadila Aini (2017),Rizka Pasadena (2013), serta Detiana (2013). Rasio likuiditas menunjukkan kemampuan perusahaan dalam memenuhi kewajiban-kewajiban jangka pendek. Perusahaan dalam membayar dividen memerlukan aliran kas keluar, sehingga harus tersedia likuiditas yang cukup. Pada current ratio terdapat kas sebagai salah satu sumber untuk pembayaran dividen, namun besarnya currentratio tidak hanya dipengaruhi oleh kas saja namun juga oleh beberapa akun seperti piutang dan persediaan.

Perusahaan yang memiliki likuiditas yang tinggi menyebabkan perusahaan memilii free cash flow yang tinggi. Sehingga, manajer pada perusahaan free cash flow yang tinggi cenderung tidak membagikan dividen tetapi menggunakan kas tersebut untuk melakukan investasi yang kurang menciptakan nilai bagi perusahaan atau digunakan untuk dirinya sendiri. Karena pembagian dividen akan meningkatkan monitoring oleh pemegang saham dan mengurangi sumber daya yang menjadi kendali manajer (Jensen, 1986). Sehingga, perusahaan yang memiliki likuiditas yang tinggi cenderung membagikan dividen yang rendah atau tidak membagikan sama sekali. Namun, perusahaan yang memiliki likuiditas yang rendah cenderung membagikan dividen yang tinggi. Hal ini sesuai dengan teori signaling (Megginson,1977) dimana walaupun likuiditasnya rendah tapi profitabilitasnya tinggi, perusahaan tidak memiliki cukup kas untuk membagikan dividen kas sehingga sebagai penggantinya perusahaan perusahaan akan membagikan dividen dalam bentuk saham (stockdividend) untuk menunjukkan kepada pemegang saham bahwa perusahaan memiliki kinerja yang bagus dalam menghasilkan profit.

Likuiditas yang terlau tinggi menunjukkan bahwa perusahaan mengalami tekanan dalam memenuhi hutang jangka pendeknya. Likuiditas yang terlau tinggi menunjukkan bahwa perusahaan mengalami tekanan dalam memenuhi hutang jangka 
pendeknya. Jika likuiditas perusahaan semakin tinggi maka kas perusahaan yang dikeluarkan akan semakin tinggi pula hal, maka dividen tersebut dibagi para investor menjadi semakin kecil.Hasil penelitian diatas sejalan dengan penelitian yang dilakukan Arilaha (2009) didukung oleh Rizki (2012) yang menyatakan bahwa likuiditas yang terlalu tinggi berdampak pada pembayaran dividen yang semakin kecil. Namun penelitian ini tidak sejalan dengan penelitian yang dilakukan oleh Karami (2013) dan Parica, dkk (2013) yang menyebutkan bahwa likuiditas berpengaruh signifikan terhadap kebijakan dividen.

\section{Pengaruh Free Cash Flow terhadap Kebijakan Dividen}

Berdasarkan hasil pengolahan data diperoleh koefisien regresi likuiditas -115 dan tingkat signifikan 0,790. Hal tersebut menunjukkan bahwa free cash flow tidak mempunyai pengaruh terhadap kebijakan dividen. Sejalan dengan penelitian Free cash flow perusahaan tidak berpengaruh terhadap kebijakan dividen. Hasil penelitian ini mendukung penelitian sebelumnya yang dilakukan oleh Endang dan Farhan (2010) yang juga menemukan bahwa free cash flow tidak memiliki pengaruh terhadap kebijakan dividen.

Penelitian ini menemukan bahwa besar kecilnya arus kas bebas tidak mempengaruhi tinggi rendahnya pembagian dividen. Apabila perusahaan menginginkan untuk memaksimumkan kekayaan pemegang saham dengan membagikan dividen sedangkan kondisi arus kas bebas tidak memungkinkan, perusahaan dapat menggunakan pendanaan eksternal. Sesuai dengan konsep Pecking Order Theory yang mengemukakan bahwa perusahaan cenderung mengutamakan pendanaan internal guna membayar dividen bila kebutuhan dana kurang maka digunakan dana eksternal sebagai tambahannya.Namun Penelitian ini bertentangan dengan penelitian yang dilakukan oleh Nurdiana (2007), Yunita (2008) yang menemukan bahwa free cash flow memiliki pengaruh terhadap dividen payout ratio (DPR). Hasil ini juga didukung oleh Rosdini (2009) yang menyatakan bahwa semakin tinggi free cash flow maka semakin tinggi kebijkan dividen atau semakin rendah free cash flow maka semakin rendah kebijakan dividen.

Pengaruh Likuiditas dan Free Cas Flow terhadap kebijakan dividen dengan Good Corporate Governance sebagai Variabel Intervening. 
Dari hasil perbandingan regresi tahap 1 dan 2, dapat peneliti simpulkan bahwa ada pengaruh likuiditas dan free cash flow terhadap kebijakan dividen dengan good corporate governance sebagai variabel intervening atau variabel perantanya.Hal ini dapat dilihat dengan adanya perubahan pada uji $\mathrm{t}$ sebelum menambahkan good corporate governance dan setelah menambahkan good corporate governance sebagai variabel interveningnya.Hasil Uji t tanpa ditambahkan variabel interveningnya adalah pada ikuiditas sebesar -0,583 dan free cash flow -0,722. Sedangkan hasil Uji T setelah ditambahkan dengan variabel interveningnya yaitu good corporate governance berubah untuk likuiditas menjadi 0,254 dan free cash flow -275. Hasil diatas menunjukan bahwa Hipotesis 3 (H3) dapat diterima yaitu terdapat pengaruh likuiditas dan free cash flow terhadap kebijakan dividen dengan good corporate governance sebagai variabel intervening. Teori (Effendi,2009) dalam bukunya The Power of Good Corporate Governance, penerapan good corporate governance adalah suatu sistem pengendalian internal perusahaan yang memiliki tujuan utama mengelola risiko yang signifikan guna memenuhi tujuan bisnisnya melalui pengamanan aset perusahaan dan meningkatkan nilai investasi pemegang saham dalam jangka panjang. Hal ini menunjukan bahwa dengan adanya penerapan good corporate governanace dalam suatu perusahaan dapat membantu pengelolahan manajemen dalam suatu perusahaan.Perubahan variabel independen dan penambahan variabel interveningmerupakan kontribusi dalam penelitian ini sehingga belum adanya penelitian terdahulu yang dapat dijadikan sebagai pembanding dan pendukung hasil yang diperoleh. Penelitian ini bertentangan dengan penelitian Indah dkk (2010) dengan variabel yang berbeda yaitu leverage, profitabilitas dan growth yang menyatakan bahwa dengan penerapan good corporate governance tidak ada pengaruh dalam suatu perusahaan.

\section{KESIMPULAN}

Penerapan Good Corporate Governance (GCG) dalam suatu perusahaan bertujuan untuk memaksimalkan nilai perusahaan dalam bentuk peningkatan kinerja (high performance) serta citra perusahaan yang baik (good corporate image).Sesuai dengan hasil penelitian yang telah dianalisis,prinsip-prinsip Good Corporate Governance (GCG)sudah diterapkan dalam perusahaan sampel.Dengan catatan perusahaan sampel kedepanya dapat lebih memaksimalkan lagi penerapan Good 
Corporate Governance (GCG) di perusahaan masing-masing secara konsisten dengan menjalankan seluruh prinsip Good Corporate Governance (GCG) yang ada.

\section{DAFTAR PUSTAKA}

Ambarwati,N.S; Gede Adi Y. dan Ni Kadek S.(2015). Pengaruh Modal Kerja,Likuiditas,Aktivitas dan Ukuran Perusahaan Terhadap Profitabilitas pada PerusahaanManufaktur yang Terdaftar di Bursa EfekIndonesia. EJurnal S1.

Daniri, Mas Achmad. 2006. Good Corporate Governance: Konsep dan Penerapannya dalam Konteks Indonesia. Jakarta: PT Ray Indonesia.

Darmawati, Deni. 2006. Pengaruh Karakteristik Perusahaan dan Faktor Regulasi Terhadap Kualitas Implementasi Corporate Governance. Simposium Nasional Akuntansi 9 Padang. hal.1-23.

Darmawati, dkk. 2005. Hubungan Corporate Governance dan Kinerja Perusahaan. Jurnal Riset Akuntansi Indonesia. Vol.8, No.1, hal.65-81.

Deitiana, Tita. (2009). Faktor - Faktor yang Mempengaruhi Kebijakan Pembayaran Dividen Kas. Jurnal Bisnis dan Akuntansi 11(1) : 57-64

Dewi, Sisca Christianty. (2008). Pengaruh Kepemilikan Manajerial, Kepemilikan Institusional, Kebijakan Hutang, Profitabilitas dan Ukuran Perusahaan terhadap Kebijakan Dividen. Jurnal Akuntansi danBisnis. 10(1): 47-58

Islamiyah, Rizki. 2012. "Pengaruh Free Cash Flow, Profitabilitas, Likuiditas, Leverage dan Growth Terhadap Kebijakan Dividen Pada Perusahaan Manufaktur di BEI'. Surabaya : STIE Perbanas Surabaya.

Ita, Lopolusi. 2013. "Analisis faktor-faktor yang mempengaruhi kebijkan dividen sector manufaktur yang terdapat di PT Bursa Efek Indonesia periode 2007$2011 "$.

Lilyana dan Jurica Lucyanda. 2012. "Pengaruh Free Cash Flow dan Struktur Kepemilikan Terhadap Dividend Payout Ratio.

Mahendra, Alfredo DJ. 2011. Pengaruh Kinerja Keuangan Terhadap NilaiPerusahaan (Kebijakan Deviden Sebagai Variabel Moderating) Pada Perusahaan Manufaktur Di Bursa Efek Indonesia. Tesis Program Pascasarjana Universitas Udayana Denpasar.

Marpaung, Elyzabet Indrawati dan Bram Hadianto. 2009. Pengaruh Profitabilitas dan Kesempatan Investasi Terhadap Kebijakan Dividen: Studi Empirik Pada Emiten Pembentuk Indeks LQ45 di Bursa Efek Indonesia. Jurnal Akuntansi. Vol.1, No.1, hal. 70-84.

Munawir. 2004. Analisis Laporan Keuangan. Yogyakarta : Liberty.

Rosdini, Dini. 2009. "Pengaruh Free Cash Flow Terhadap Dividend Payout Ratio". 
Santoso, Eko Budi. 2005. Analisis Pengaruh Tata Kelola Perusahaan yang Baik Terhadap Rasio Pembayaran Dividen. Tesis Dipublikasikan. Yogyakarta: FEUGM.

Siallagan, Hamonangan dan Mas'ud Machfoedz. 2006. Mekanisme Corporate Governance, Kualitas Laba, dan Nilai Perusahaan. Simposium Nasional Akuntansi 9 Padang. hal.1-23.

Sugiarto. 2008. Kebijakan Dividend Perusahaan-Perusahaan Terbuka Non Keuangan Sugiyono, 2007. Statistika Untuk Penelitian. Bandung: CV Alfabeta.

Suharli, M. 2007. Pengaruh Profitabilitas dan Invesment Opportunity Set

Suharli, Michell. 2007. Pengaruh Profitability dan Investment Oppurtunity Set

Sulistiyowati, Anggaraini, dan Utaminingtyas (2010), Pengaruh Profitabilitas, Laverage, Growt terhadap kebijakan deviden dengan CGC sebagai variable intervening.

Sunarto \& Kartika, A. 2003. Analisis Faktor-faktor yang Mempengaruhi Dividen Kas. JurnalEkonomi dan Bisnis, Vol.8, No.1.

terhadap Kebijakan Dividen Tunai dengan Likuiditas sebagai Variabel Penguat. Jurnal Akuntansidan Keuangan. Vol.9, No.1, hal 9-17.

Terhadap Kebijakan Dividen Tunai dengan Likuiditas Sebagai Variabel Penguat. Jurnal Akuntansi dan Keuangan. Vol.9, No.1, hal.9-17.

www.idx.co.id (diakses Juni 2019).

www.yahoofinance.com (diakses Juni 2019).

yang dikontrol Keluarga. Akuntabilitas. Vol.7, No.2, hal.135-149. 